\title{
Chemical characterization and antioxidant activity of Eryngium pseudothorifolium and E. thorifolium essential oils
}

\author{
Gülsen TEL-ÇAYAN $1 *$ (D), Mehmet Emin DURU 2 (D) \\ 1 Department of Chemistry and Chemical Processing Technologies, Muğla Vocational School, Muğla Sitkı Koçman \\ University, Muğla 48000, Turkey. \\ 2 Department of Chemistry, Faculty of Sciences, Muğla Sıtkı Koçman University, Muğla 48000, Turkey. \\ * Corresponding Author. E-mail: gulsentel@mu.edu.tr (G.T.Ç.); Tel. +90-252-212 2038.
}

Received: 05 April 2019 / Revised: 07 August 2019/ Accepted: 10 August 2019

\begin{abstract}
The chemical characterization and antioxidant activities of essential oils of Eryngium pseudothoriifolium Contandr. \& Quézel and E. thorifolium Boiss., endemic plant species from Turkey, were investigated. The essential oils obtained by hydro-distillation were analyzed by GC/FID and GC/MS. Thirty and twenty-three compounds representing $99.5 \%$ and $99.7 \%$ were identified in E. pseudothoriifolium and E. thorifolium essential oils, respectively. The main component of E. pseudothoriifolium oil was falcarinol (84.8\%) whereas those of E. thorifolium were a-pinene (31.9\%), caryophyllene oxide $(21.6 \%)$ and hexahydrofarnesylacetone $(11.1 \%)$. The antioxidant capacities of the essential oils were tested by several methods including $\beta$-carotene-linoleic acid, radical scavenging (DPPH and ABTS) and reducing power (CUPRAC) assays. The essential oil of E. pseudothoriifolium with the high amount of falcarinol exhibited the best antioxidant activity in all assays. The results of the present study supported the possible uses of Eryngium essential oils as a valuable source of natural antioxidant in food and pharmaceutical industries.
\end{abstract}

KEYWORDS: Eryngium pseudothoriifolium; Eryngium thorifolium; essential oil; chemical characterization; antioxidant activity.

\section{INTRODUCTION}

The Apiaceae (Umbelliferae) family comprises aromatic plants used as a food, spices, and for their utility in pharmacy, agriculture, and cosmetics [1]. Apiaceae are valuable sources of essential oils which are extracted by steam or hydro-distillation from flowers, seeds, leaves, stems, bark, and roots of plants. The major constituents of the Apiaceae essential oils are monoterpenes, sesquiterpenes and phenylpropanoids [2].

The genus Eryngium is an important member of the family Apiaceae and contains about 317 species distributed in temperate regions of every continent, mainly in Eurasia, North Africa, North and South America, and Australia [3, 4]. In Turkey, 23 species (24 taxa) are recorded, and ten of them are reported to be endemic [5]. Eryngium species are known as 'boğa dikeni' in Turkish folk medicine and are used to treat a wide range of ailments. The roots of Eryngium species are used to treat several inflammatory disorders, sinusitis, goiter, edema, urinary infections and inflammations, snake or scorpion bites, while the roots and leaves are used for infertility, and the herbs are used for wound healing and as food when they are fresh [68].

Phytochemical studies performed on Eryngium species including several secondary metabolites such as terpenoids, steroids, triterpenoid saponins, polyacetylenes, phenolics, flavonoids, coumarins and rosmarinic acid derivatives $[9,10]$. Antioxidant, cytotoxic, anti-inflammatory, antimicrobial, antimalarial, antidiabetic and anti-mutagenic activities have been reported from Eryngium species [11, 12].

The aim of the present work was to evaluate the chemical characterization and antioxidant effects of the essential oils from aerial parts of E. pseudothoriifolium Contandr. \& Quézel and E. thorifolium Boiss., which are endemic in Muğla, Turkey.

How to cite this article: Tel-Çayan G, Duru ME. Chemical characterization and antioxidant activity of Eryngium pseudothoriifolium and $E$. thorifolium essential oils. J Res Pharm. 2019; 23(6): 1106-1114. 


\section{RESULTS AND DISCUSSION}

\subsection{Chemical characterization of the essential oils}

The yields of the essential oil from aerial parts of E. pseudothoriifolium Contandr. \& Quézel and E. thorifolium Boiss. were 0.65 and $0.48 \%$. The essential oils obtained from E. pseudothoriifolium and E. thorifolium were analyzed by using the gas chromatography (GC) and GC/mass spectrometry (GC-MS) techniques. The chemical characterization of the essential oils, relative percentage (\%) and Kovats index of compounds are given in Table 1. Thirty compounds were identified in the essential oil of E. pseudothoriifolium representing $99.5 \%$ of the total oil; falcarinol $(84.8 \%)$ was found as the main compound. A total of twenty-three compounds were found in the essential oil of E. thorifolium, representing about $99.7 \%$ of total oil. a-Pinene (31.9\%), caryophyllene oxide $(21.6 \%)$ and hexahydrofarnesylacetone $(11.1 \%)$ were major compounds in the essential oil.

Table 1. Chemical characterization of the essential oils of E. pseudothoriifolium and E. thorifolium.

\begin{tabular}{|c|c|c|c|c|c|c|}
\hline No & Compounds ${ }^{a}$ & $\begin{array}{c}\text { E. } \\
\text { pseudothoriifolium } \\
\left(\%{ }^{\mathrm{b}}\right)\end{array}$ & $\begin{array}{c}E . \\
\text { thorifolium } \\
\left(\%^{\mathrm{b}}\right)\end{array}$ & $\mathbf{R I}^{\mathbf{c}}$ & LRI $^{d}$ & $\begin{array}{l}\text { Identification } \\
\text { Methods }\end{array}$ \\
\hline 1 & (E)-3-Nonene & 0.1 & $t r$ & 921 & 924 & MS, RI \\
\hline 2 & $a$-Pinene & - & 31.9 & 930 & 939 & Co-GC, MS, RI \\
\hline 3 & $p$-Cymene & 0.1 & - & 1021 & 1020 & Co-GC, MS, RI \\
\hline 4 & Nonanal & 0.2 & 0.8 & 1075 & 1073 & MS, RI \\
\hline 5 & $a$-Isophorone & 0.1 & - & 1090 & 1088 & MS, RI \\
\hline 6 & (E)-2-Nonenal & 0.2 & 0.4 & 1118 & 1112 & MS, RI \\
\hline 7 & 4-Ethyl-o-xylene & $t r$ & - & 1125 & 1124 & MS, RI \\
\hline 8 & Prehnitene & 0.1 & - & 1150 & 1152 & MS, RI \\
\hline 9 & 2-Hexylfuran & - & 0.5 & 1163 & 1165 & MS, RI \\
\hline 10 & 2-Nonen-1-ol & 0.6 & 0.4 & 1168 & 1171 & MS, RI \\
\hline 11 & (E)-3-Dodecene & 0.3 & 2.2 & 1218 & 1215 & MS, RI \\
\hline 12 & (Z)-7-Decenal & 0.1 & - & 1232 & 1230 & MS, RI \\
\hline 13 & Thymol & 0.1 & 0.7 & 1294 & 1289 & Co-GC, MS, RI \\
\hline 14 & a-Methyl naphtalene & 0.2 & - & 1304 & 1309 & MS, RI \\
\hline 15 & Benzocycloheptatriene & 0.1 & 0.8 & 1351 & 1354 & MS, RI \\
\hline 16 & Dimethyl salicylate & - & 0.4 & 1382 & 1380 & MS, RI \\
\hline 17 & (E)-7-Tetradecene & 1.5 & - & 1421 & 1425 & MS, RI \\
\hline 18 & (Z)- $\beta$-Farnesene & 0.5 & - & 1443 & 1445 & MS, RI \\
\hline 19 & Dihydroactinidiolide & 0.2 & 0.4 & 1488 & 1483 & MS, RI \\
\hline 20 & Caryophyleine-(13) & $\operatorname{tr}$ & 1.3 & 1509 & 1499 & MS, RI \\
\hline 21 & 4-(2-Methy-3-oxocyclohexyl)butanal & 0.6 & 1.8 & 1517 & 1515 & MS, RI \\
\hline 22 & Spathulenol & 1.3 & 8.5 & 1576 & 1572 & Co-GC, MS, RI \\
\hline 23 & Caryophylene oxide & 1.5 & 21.6 & 1580 & 1578 & Co-GC, MS, RI \\
\hline 24 & Isoaromadendrene epoxide & $\operatorname{tr}$ & 3.7 & 1582 & 1585 & Co-GC, MS, RI \\
\hline 25 & Benzophenone & 0.1 & - & 1590 & 1601 & MS, RI \\
\hline 26 & 1-Hexadecene & 1.6 & 1.8 & 1615 & 1602 & MS, RI \\
\hline 27 & $\delta$-Cadinol & - & 1.5 & 1646 & 1651 & MS, RI \\
\hline 28 & cis-Lanceol & 0.2 & 3.3 & 1761 & 1737 & MS, RI \\
\hline 29 & Hexanoic acid decyl ester & 0.3 & - & 1779 & 1776 & MS, RI \\
\hline 30 & Cetyl alcohol & 0.4 & 2.0 & 1824 & 1826 & MS, RI \\
\hline 31 & Hexahydrofarnesyl acetone & 3.4 & 11.1 & 1923 & 1935 & MS, RI \\
\hline 32 & $a$-Hexylcinnamaldehyde & 0.8 & - & 1964 & 1690 & MS, RI \\
\hline 33 & Hexadecanoic acid ethyl ester & 0.1 & - & 1976 & 1968 & MS, RI \\
\hline 34 & Falcarinol & 84.8 & - & 1987 & 1906 & MS, RI \\
\hline 35 & $a$-Kaurene & - & 3.2 & 2045 & 2044 & MS, RI \\
\hline 36 & Oleyl alcohol & - & 1.4 & 2072 & 2061 & MS, RI \\
\hline \multicolumn{2}{|r|}{ Total identified (\%) } & 99.5 & 99.7 & & & \\
\hline
\end{tabular}

${ }^{a}$ Compounds are listed in order of their elution from a DB-5 fused silica column. ${ }^{b}$ Percentage concentration. ${ }^{\mathrm{c}}$ Retention index on DB-5 fused silica column. ${ }^{d}$ Linear retention index taken from Adams (2007) and /or NIST 08 (2008). e Identification methods: Co-I: Co-injection: based on comparison with authentic compounds; MS: based on comparison with WILEY, ADAMS and NIST 08 MS databases; RI: based on comparison of calculated with those reported in ADAMS and NIST 08. 
Çelik et al., [13] investigated the chemical composition of the essential oil of E. thorifolium by direct thermal desorption (DTD) - GC/MS analyses and a-pinene (58.65 33.52\%), 7-exo-ethenylbicyclo [4.2.0] oct-1ene $(10.56 \pm 3.62 \%)$, limonene $(3.14 \pm 5.14 \%)$ and $(\mathrm{E})$-Oct-2-enal $(3.04 \pm 4.68 \%)$ were identified as major compounds. Usluer et al. [14] were previously studied the chemical compositions of hexane extracts of $E$. pseudothoriifolium and E. thorifolium using soxhlet extraction technique by GC-MS. Falcarinol $(82.89 \%), 6,10,14-$ trimethyl pentadecanone $(3.24 \%)$ and caryophyllene $(2.15 \%)$ were identified as major compounds in the hexane extract of E. pseudothoriifolium while cis-verbenyl acetate (24.84\%), caryophyllene oxide (18.17\%), (E)Farnesene epoxide (12.72\%), and Selina 4,11-diene 2-ol (9.56\%) were detected as main components in the hexane extract of E. thoriifolium. The chemical composition of essential oil of E. pseudothoriifolium was described for the first time in this study.

In earlier reports, the chemical contents of essential oils of different Eryngium species have been studied. The essential oil of E. billardieri was analyzed by Sefidkon et al. [15], $\alpha$-muurolene (42.0\%), $\beta$-gurjunene (17.0\%), $\delta$-cadinene $(6.2 \%)$ and valencene $(5.7 \%)$ were identified as major compounds. Klein-Junior et al. [16] reported spathulenol (36.0\%) and 2, 3, 6-trimethyl benzaldehyde (15.7\%) as the major compounds in E. floribundum; bicyclogermacrene (17.2\%) and cyclocolorenone (14.7\%) in E. nudicaule; sesquicineole (21.3\%), pentadecane (53.5\%), globulol (18.6) and aromadendrene (9.1\%) in E. horridum. In the study of Medbouhi et al. [4] the chemical compositions of E. triquetrum essential oils from 25 different locations were investigated and falcarinol (63.5-90.6\%) was found to be highly dominant in the essential oils, followed by octanal (1.0-12.8\%). 2-Dodecen-1-al (46.68\%) and caprinic alcohol (14.80\%) in E. foetidum essential oil and a-bisabolol (32.6\%), acurcumene $(6.5 \%)$ and a-selinene $(5.4 \%)$ in E. tricuspidatum essential oil were reported as major compounds $[17,18]$. A comparison of the major compounds of the essential oil from different species of Eryngium is depicted in Table 2. The main component of some Eryngium species such as E. campestre (13.8\%) [2], E. amethystinum (56.7\%) [2], E. eriophorum (35.1\%) [16], E. pandanifolium (28.9\%) [16], E. maritimum (10.4-15.9\%) [19], E. serbicum (19.7\%) [20] and E. yuccifolium (18.3\%) [21] was Germacrene D. Falcarinol also was found to be principal components in E. triquetrum (86.9\%) [4] and E. palmatum (34.9\%) [9] essential oils.

Our results have similarities and differences in the literature. The obtained and literature results show that not only the different species but also the chemical composition of the same species may be different. These differences originated due to the location of collection area, climatic conditions and genetic factors [30].

\subsection{Antioxidant activity}

The antioxidant properties of the essential oils of E. pseudothoriifolium and E. thoriffolium were evaluated using $\beta$-carotene-linoleic acid, DPPH free radical scavenging, ABTS cation radical scavenging and CUPRAC assays. The antioxidant activities of the essential oils were compared with the synthetic antioxidants, BHA and a-tocopherol, which were used as standards. The essential oils were tested at different concentrations and the results were given as inhibition percentage (\%) at $200 \mu \mathrm{g} / \mathrm{mL}$ concentration of the essential oils in Table 3.

In $\beta$-carotene-linoleic acid assay, E. pseudothoriifolium essential oil $(74.81 \pm 1.15 \%)$ showed higher lipid peroxidation inhibition activity than E. thoriifolium essential oil $(41.72 \pm 1.30 \%)$. The essential oil of E. pseudothoriifolium showed the higher radical scavenging activity with inhibition values of $57.96 \pm 0.27 \%$ and $63.46 \pm 1.38 \%$ at $200 \mu \mathrm{g} / \mathrm{mL}$ concentration in DPPH ${ }^{\bullet}$ and $\mathrm{ABTS}{ }^{*}+$ assays, respectively (Table 3 ).

The essential oil of E. pseudothoriifolium (1.22 \pm 0.07 absorbance) was active than E. thorifolium essential oil (0.44 \pm 0.07 absorbance). As shown in Figure 1, E. pseudothorifolium essential oil was found to be higher reductant than a-tocopherol at 100 and $200 \mu \mathrm{g} / \mathrm{mL}$ concentration.

The essential oils of Eryngium species are known to be rich in falcarinol. The significant antioxidant activity of E. pseudothoriifolium essential oil in all assays can be attributed to high amounts of falcarinol as reported in the literature [4]. This is the first comprehensive study about the antioxidant activities of the essential oils of E. pseudothoriifolium and E. thorifolium.

According to our knowledge, Eryngium genus has approximately 250 species throughout the world, the limited number of essential oils (E. maritimum, E. triquetrum, E. tricuspidatum and E. foetidum) was investigated for their antioxidant activities. Radical scavenging activities of the essential oils of E. maritimum collected from five different regions were determined by using DPPH ${ }^{\bullet}\left(\mathrm{IC}_{50}: 104-141 \mu \mathrm{g} / \mathrm{mL}\right)$ and $\mathrm{ABTS}^{\bullet}+\left(\mathrm{IC}_{50}: 39-71 \mu \mathrm{g} / \mathrm{mL}\right)$ radicals [31]. E. triquetrum essential oil was reported to exhibit high $\mathrm{DPPH} \cdot$ radical scavenging activity $\left(\mathrm{IC}_{50}\right.$ : 
$28.68 \mu \mathrm{g} / \mathrm{mL}$ ) [4]. In a different study, Thomas et al. [22] investigated antioxidant properties the essential oils of leaf, stem, and root of E. foetidum. In DPPH assay, $\mathrm{IC}_{50}$ values for the leaf, stem and root oils were $56 \mu \mathrm{g} / \mathrm{mL}$, $46 \mu \mathrm{g} / \mathrm{mL}$, and $54.5 \mu \mathrm{g} / \mathrm{mL}$ respectively, while the leaf oil showed the highest reducing potential in the FRAP assay. Antioxidant activity of E. tricuspidatum essential oil (DPPH assay: $\mathrm{IC}_{50}: 510 \mu \mathrm{g} / \mathrm{mL}$; FRAP assay: reducing the power of oil increases from 0.0188 at $5 \mu \mathrm{g} / \mathrm{mL}$ to 0.5016 at $1000 \mu \mathrm{g} / \mathrm{mL}$ ) was studied by Merghache et al. [18]. Our results are comparable to those of earlier studies.

Table 2. Major compounds of essential oils from Eryngium species reported.

\begin{tabular}{|c|c|c|}
\hline Eryngium species & Major compounds & Ref. \\
\hline E. campestre & Germacrene D (13.8\%), allo-Aromadendrene $(7.7 \%)$ & [2] \\
\hline E. amethystinum & Germacrene D (56.7\%), $\beta$-Elemene $(4.7 \%)$, Bicyclogermacrene $(3.3 \%)$ & [2] \\
\hline E. triquetrum & Falcarinol (86.9\%), Octanal (1.8\%) & [4] \\
\hline E.palmatum & Falcarinol (34.9\%), Octanal (31.7\%), $a$-Curcumene (5.9\%) & [9] \\
\hline E. creticum & Hexanal (52.90\%), Heptanal (13.90\%), & [13] \\
\hline E. thorifolium & a-Pinene (58.65\%), 7-exo-Ethenylbicyclo[4.2.0]oct-1-ene (10.56\%) & [13] \\
\hline E. billardieri & $a$-Muurolene (42.0\%), $\beta$-gurjunene (17.0\%), $\delta$-cadinene $(6.2 \%)$ & [15] \\
\hline E. floribundum & Spathulenol (36.0\%), 2,3,6-Trimethyl benzaldehyde (15.7\%) & [16] \\
\hline E. eriophorum & Germacrene D (35.1\%), Bicyclogermacrene $(10.4 \%)$ & [16] \\
\hline E. nudicaule & Bicyclogermacrene (17.2\%), Cyclocolorenone $(14.7 \%)$ & [16] \\
\hline E. horridum & Pentadecane (53.5\%), Globulol (18.6), Aromadendrene (9.1\%) & [16] \\
\hline E. pandanifolium & Germacrene D (28.9\%), Bicyclogermacrene $(12.8 \%)$ & [16] \\
\hline E. foetidum & 2-Dodecen-1-al (46.68\%), Caprinic alcohol (14.80\%) & {$[17]$} \\
\hline E. tricuspidatum & $a$-Bisabolol (32.6\%), $a$-Curcumene (6.5\%), Ledol (4.8\%) & [18] \\
\hline E. maritimum & $\begin{array}{l}\text { Aerial oil: Germacrene D }(10.4 \%) \text {, 2,4,5-Trimethylbenzaldehyde }(8.3 \%) \text {, } \\
\text { Spathulenol }(4.5 \%)\end{array}$ & \\
\hline
\end{tabular}

Flower oil: Germacrene D (15.9\%), 2,4,5-Trimethylbenzaldehyde (6.7\%), Bicyclogermacrene $(4.7 \%)$

\begin{tabular}{llll}
\hline E. serbicum & Germacrene D $(19.7 \%), \beta$-elemene $(10.0 \%)$, spathulenol (6.9\%) & {$[20]$} \\
\hline E. palmatum & Sesquicineole $(21.3 \%)$, caryophyllene oxide $(16.0 \%)$, spathulenol $(16.0 \%)$ & {$[20]$} \\
\hline E. yuccifolium & Germacrene D $(18.3 \%)$, terpinolene $(17.8 \%)$, bicyclogermacrene $(8.8 \%)$ & {$[21]$} \\
\hline E. foetidum & $\begin{array}{l}\text { Leaf oil: } \\
(\text { (E)-2-Dodecenal }(28.43 \%), ~ 13 \text {-tetradecenal }\end{array}$ & $(27.45 \%)$, dodecanal &
\end{tabular}

Stem oil: Dodecanal (20.21\%), 2,4,5-trimethylbenzaldehyde (18.43\%) and $(E)$ -

2-dodecenal (8.27\%)

Root oil: 2,4,5-trimethylbenzaldehyde (56.08\%), 13-tetradecenal (9.26\%) (E)-2dodecenal $(7.65 \%)$

E. glomeratum Aerial oil: cis-Chrysanthenyl acetate (27.3\%), 14-Hydroxy-a-muurolene (19.6\%), $a$-Bisabolol (12\%)

Root oil: $\beta$-Oplopenone (20\%), Di-epi-Cedrenoxide (15.9\%), $\delta$-Selinene (15.6\%)

E. barrelieri $\quad$ Aerial oil: $\beta$-Selinene (20.1\%), Di-epi-Cedrenoxide (18.7\%), $\beta$-oplopenone
$(10.6 \%)$

Root oil: Di-epi-Cedrenoxide (26.5\%), $\beta$-oplopenone (20.3\%), Acoradiene $(10.5 \%)$

\begin{tabular}{llc}
\hline E. caeruleum & $\begin{array}{l}\text { Cyclobuta }[1,2,3,4] \text { dicyclooctene, hexadecahydro }(47.03 \%), n \text {-Hexadecanoic } \\
\text { acid }(11.16 \%), \text { Linoleic acid }(5.41 \%)\end{array}$ & {$[24]$} \\
\hline E. duriaei & $\begin{array}{l}a \text {-Neocallitropsene }(26.0 \%), \beta \text {-Betulenal }(16.2 \%), 14 \text {-hydroxy- } \beta \text {-caryophyllene } \\
(13.4 \%)\end{array}$ & {$[25]$} \\
\hline E. paludosum & $\gamma$-Terpinene $(12.9 \%), \beta$-bisabolene $(12.2 \%)$, germacrene D $(7.6 \%)$ & {$[26]$} \\
\hline E. rosulatum & $\beta$-Elemene $(16.0 \%)$, bicyclogermacrene $(12.5 \%), \delta$-elemene $(7.0 \%)$ & {$[27]$} \\
\hline E. campestre & $\gamma$-Cadinen-15-al $(23.3 \%)$, spathulenol $(10.7 \%)$, octanoic acid $(9.8 \%)$ & {$[28]$} \\
\hline E. bungei & Cumin alcohol $(55.3 \%)$, terpinolene $(14.6 \%)$, carvacrol $(8.9 \%)$ & {$[29]$} \\
\hline
\end{tabular}


Table 3. Antioxidant activities of the essential oils of E. pseudothoriifolium and E. thoriifolium by $\beta$-carotenelinoleic acid, DPPH•, ABTS ${ }^{*}$ and CUPRAC assays ${ }^{\circ}$.

\begin{tabular}{|c|c|c|c|c|c|}
\hline & & $\begin{array}{l}\beta \text {-carotene-linoleic } \\
\text { acid assay }\end{array}$ & $\begin{array}{l}\text { DPPH・ } \\
\text { assay }\end{array}$ & $\begin{array}{l}\text { ABTS } \bullet+ \\
\text { assay }\end{array}$ & $\begin{array}{l}\text { CUPRAC } \\
\text { assay }^{\text {b }}\end{array}$ \\
\hline \multirow[t]{2}{*}{ Species } & E. pseudothorifolium & $74.81 \pm 1.15$ & $57.96 \pm 0.27$ & $63.46 \pm 1.38$ & $1.22 \pm 0.07$ \\
\hline & E. thoriifolium & $41.72 \pm 1.30$ & $31.02 \pm 0.59$ & $49.72 \pm 1.34$ & $0.44 \pm 0.07$ \\
\hline \multirow[t]{2}{*}{ Standards } & BHAc $^{c}$ & $91.91 \pm 0.38$ & $88.39 \pm 0.26$ & $86.73 \pm 0.10$ & $2.90 \pm 0.21$ \\
\hline & a-Tocopherolc & $92.70 \pm 0.69$ & $90.15 \pm 0.51$ & $85.94 \pm 0.14$ & $1.04 \pm 0.07$ \\
\hline
\end{tabular}

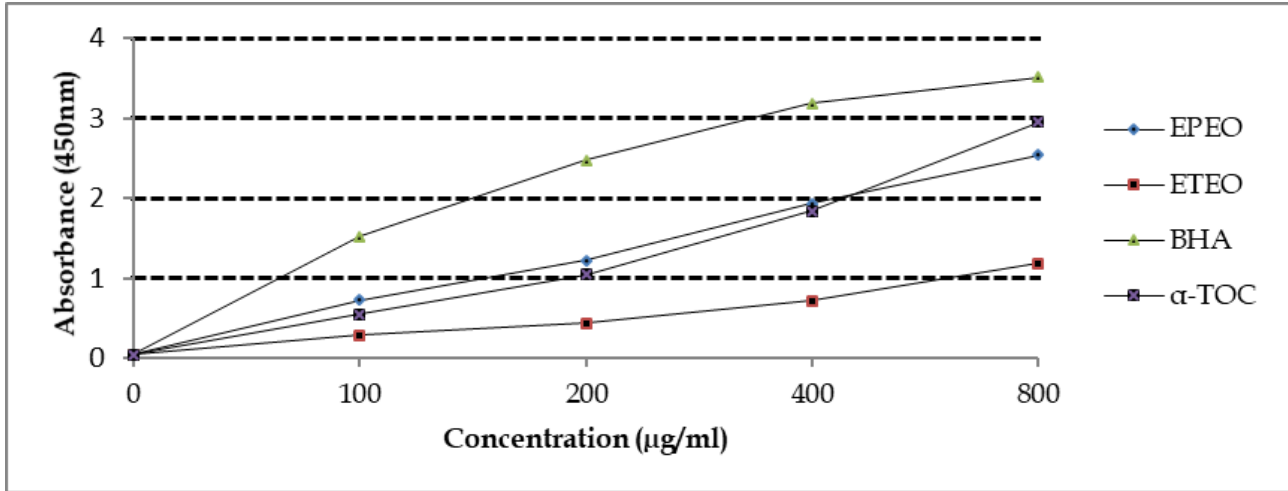

Figure 1. Cupric reducing antioxidant capacity (CUPRAC) essential oils of Eryngium species (EPEO, and ETEO), BHA and a-tocopherol using spectrophotometric detection of the $\mathrm{Cu}^{2+}-\mathrm{Cu}^{1+}$ transformation.

\section{CONCLUSIONS}

This study is the first report of comprehensive antioxidant effects and detailed chemical characterization of these essential oils. In fact the essential oil of E. pseudothoriifolium can be considered as rich source of falcarinol. The high antioxidant activity of E. pseudothoriifolium essential oil is the result of high amount of falcarinol. In conclusion, our results indicate that Eryngium species could be explored as a natural source of food supplements and therapeutic applications.

\section{MATERIALS AND METHODS}

\subsection{Plant materials}

The aerial parts of E. pseudothoriifolium and E. thorifolium were collected from Muğla, Turkey in 2016. The plants were identified by Dr. Hasan Yıldırım at Ege University, Izmir, Turkey. The voucher specimen has been deposited at the herbarium of Natural Products Laboratory of Muğla Sitkı Koçman University with voucher no MU1141 (for E. pseudothoriifolium) and MU1145 (for E. thorifolium).

\subsection{Isolation and analysis of the essential oil}

The essential oils of dried aerial parts of E. pseudothoriifolium and E. thorifolium were hydro-distillated in a Clevenger-type apparatus for $4 \mathrm{~h}$. The oils were dried over anhydrous sodium sulfate and stored under $+4^{\circ} \mathrm{C}$ until analyzed.

The essential oils were analyzed by GC-FID and GC-MS techniques. A Flame Ionization Detector (FID) and a DB- 5 fused silica capillary non-polar column $(30 \mathrm{~m} \times 0.25 \mathrm{~mm}$ id., film thickness $0.25 \mu \mathrm{m})$ were used for GC analyses. The injector temperature and detector temperature were adjusted 250 and $270^{\circ} \mathrm{C}$, respectively. Carrier gas was He at a flow rate of $1.4 \mathrm{~mL} / \mathrm{min}$. The sample size was $0.1 \mu \mathrm{L}$ with a split ratio of 20:1. The initial oven temperature was held at $60^{\circ} \mathrm{C}$ for $5 \mathrm{~min}$, then increased up to $240^{\circ} \mathrm{C}$ with $4^{\circ} \mathrm{C} / \mathrm{min}$ increments and held at this temperature for $10 \mathrm{~min}$. The percentage composition of the essential oil was determined by the Class GC10 GC computer program.

An Ion trap MS spectrometer and a DB- $5 \mathrm{~ms}$ fused silica non-polar capillary column ( $30 \mathrm{~m} \times 0.25 \mathrm{~mm}$ ID, film thickness $0.25 \mu \mathrm{m}$ ) were used for the GC/MS analyses. The carrier gas was helium at a flow rate of 1.4 
$\mathrm{mL} / \mathrm{min}$. The oven temperature was held at $60^{\circ} \mathrm{C}$ for $5 \mathrm{~min}$, then increased up to $240^{\circ} \mathrm{C}$ with $4^{\circ} \mathrm{C} / \mathrm{min}$ increments and held at this temperature for $10 \mathrm{~min}$. Injector and MS transfer line temperatures were set at $220^{\circ} \mathrm{C}$ and $290^{\circ} \mathrm{C}$, respectively. The ion source temperature was $200^{\circ} \mathrm{C}$. The injection volume was $0.2 \mu \mathrm{L}$ with a split ratio of 20:1. EI-MS measurements were taken at $70 \mathrm{eV}$ ionization energy. Mass range was from $\mathrm{m} / \mathrm{z} 28$ to $650 \mathrm{amu}$. Scan time $0.5 \mathrm{~s}$ with 0.1 inter scan delays. Identification of components of the essential oils was based on GC retention indices and computer matching with the Wiley, NIST-2008 and TRLIB Library as well as by comparison of the fragmentation patterns of the mass spectra with those reported in the literature and whenever possible, by co-injection with authentic compounds [32].

\subsection{Antioxidant activity assays}

\subsection{1. $\beta$-carotene/linoleic acid assay}

The total antioxidant activity was determined by $\beta$-carotene-linoleic acid method based on the measurement of the inhibition of conjugated dien hydroperoxides resulting from linoleic acid oxidation with slight modifications [33]. A $\beta$-carotene-linoleic acid mixture was prepared as following: $0.5 \mathrm{mg} \beta$-Carotene in $1 \mathrm{~mL}$ of chloroform was added to $25 \mu \mathrm{L}$ linoleic acid and $200 \mathrm{mg}$ Tween 40 emulsifier mixture. After evaporation of chloroform under vacuum, $100 \mathrm{~mL}$ of distilled water saturated with oxygen, was added by vigorous shaking. One hundred-sixty microliters of this mixture was transferred into $40 \mu \mathrm{L}$ the samples at different concentrations. As soon as the emulsion was added into each tube, the zero time absorbance was measured at $470 \mathrm{~nm}$ using a 96-well microplate reader. Absorbance of the emulsion was read again at the same wavelength after incubation of the plate for $2 \mathrm{~h}$ at $50^{\circ} \mathrm{C}$. Measurement of absorbance was continued until the colour of $\beta$-carotene disappeared. BHA and a-tocopherol were used as antioxidant standards for comparison of the activity. The same procedure was repeated with used antioxidant standards and a blank. The bleaching rate ( $R$ ) of $\beta$-carotene was calculated according to Eq. 1.

$$
\mathrm{R}=\frac{\ln \frac{a}{b}}{t}
$$

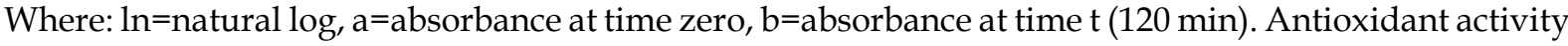
was calculated in terms of percentage inhibition relative to the control, using Eq. 2.

$$
\text { Antioxidant activity (\%) }=\frac{R_{\text {control }}-R_{\text {sample }}}{R_{\text {control }}} \times 100
$$

\subsubsection{DPPH free radical scavenging assay}

The free radical scavenging activity was determined spectrophotometrically by the DPPH assay described by Blois [34] with slight modification [33]. In its radical form, DPPH absorbs at $517 \mathrm{~nm}$, but upon reduction by an antioxidant or a radical species, its absorption decreases. Briefly, $40 \mu \mathrm{L}$ sample solutions at different concentrations were added to $160 \mu \mathrm{L} 0.4 \mathrm{mM}$ DPPH solution. Thirty minutes later, absorbance was measured at $517 \mathrm{~nm}$ by using a 96-well microplate reader. The capability of scavenging the Inhibition activity (I) was calculated using Eq. 3.

$$
\mathrm{I}(\%)=\frac{A_{\text {control }}-A_{\text {sample }}}{A_{\text {control }}} \times 100
$$

\subsubsection{ABTS cation radical scavenging assay}

The spectrophotometric analysis of $\mathrm{ABTS}^{*}$ scavenging activity was determined according to the method of Re et al. [35] with slight modifications [33]. Briefly, ABTS ${ }^{*+}$ was produced by the reaction between $7 \mathrm{mM}$ ABTS in $\mathrm{H}_{2} \mathrm{O}$ and $2.45 \mathrm{mM}$ potassium persulfate, stored in the dark at room temperature for $12 \mathrm{~h}$. The radical cation was stable in this form for more than 2 days when stored in the dark at room temperature. Before usage, the ABTS ${ }^{*}$ solution was diluted to get an absorbance of $0.708 \pm 0.025$ at $734 \mathrm{~nm}$ with ethanol. Then, 160 $\mu \mathrm{L}$ of $\mathrm{ABTS}^{\bullet+}$ solution was added to $40 \mu \mathrm{L}$ of sample solution in ethanol at different concentrations. After 10 
min, by using a 96-well microplate reader, the percentage inhibition at $734 \mathrm{~nm}$ was calculated for each concentration relative to a blank absorbance (ethanol). The scavenging capability of ABTS ${ }^{\bullet+}$ was calculated using Eq. 3.

\subsubsection{Cupric reducing antioxidant capacity (CUPRAC) assay}

The cupric reducing antioxidant capacity was determined according to the method of Apak et al. [36] with slight modifications [33]. To each well, in a 96 well plate, $50 \mu \mathrm{L} 10 \mathrm{mM} \mathrm{Cu}$ (II), $50 \mu \mathrm{L} 7.5 \mathrm{mM}$ neocuproine, and $60 \mu \mathrm{L} \mathrm{NH}_{4} \mathrm{Ac}$ buffer (1 M, pH 7.0) solutions were added. Forty microliter extract at different concentrations were added to the initial mixture so as to make the final volume $200 \mu \mathrm{L}$. After $1 \mathrm{~h}$, the absorbance at $450 \mathrm{~nm}$ was recorded against a reagent blank by using a 96-well microplate reader.

\subsection{Statistical analysis}

All data on antioxidant activity tests were the average of three parallel sample measurements. Data were recorded as mean \pm S.E.M. Significant differences between means were determined by student's-t test, $p$ values $<0.05$ were regarded as significant.

Acknowledgement: Authors would like to thank Dr. Hasan Yildırım (Faculty of Science, Department of Biology, Ege University) for the identification of the plant samples.

Author contributions: Concept - G.T.Ç., M.E.D.; Design - G.T.Ç., M.E.D.; Supervision - M.E.D.; Materials - M.E.D.; Data Collection and/or Processing - G.T.Ç., M.E.D..; Analysis and/or Interpretation - G.T.Ç., M.E.D.; Literature Search - G.T.Ç.; Writing - G.T.Ç.; Critical Reviews - G.T.Ç., M.E.D.

Conflict of interest statement: The authors declared no conflict of interest.

\section{REFERENCES}

[1] Ebadollahi A. Plant essential oils from Apiaceae family as alternatives to conventional insecticides. Ecol Balkan. 2013; 5: $149-172$

[2] Cianfaglione K, Blomme EE, Quassinti L, Bramucci M, Lupidi G, Dall'Acqua S, Maggi F. Cytotoxic essential oils from Eryngium campestre and Eryngium amethystinum (Apiaceae) growing in central Italy. Chem Biodivers. 2017; 14: e1700096. [CrossRef]

[3] Wörz A. On the distribution and relationships of the South-West Asian species of Eryngium L. (ApiaceaeSaniculoideae). Turk J Botany. 2004; 28: 85-92.

[4] Medbouhi A, Merad N, Khadir A, Bendahou M, Djabou N, Costa, J, Muselli A. Chemical composition and biological investigations of Eryngium triquetrum essential oil from Algeria. Chem Biodivers. 2018; 15: e1700343. [CrossRef]

[5] Davis PH. Flora of Turkey and the East Aegean Islands, In: Güner A, Özhatay N, Ekim T, Baser KHC. (Eds). Edinburgh University Press, Edinburgh, 2000, Vol. 11, pp. 136-138.

[6] Sezik E, Yesilada E, Tabata M, Honda G, Takaishi Y, Fujita T, Tanaka T, Takeda Y. Traditional medicine in Turkey VIII. Folk medicine in East Anatolia; Erzurum, Erzincan, Agri, Kars, Igdir provinces. Economic Bot. 1997; 51: 195211. [CrossRef]

[7] Yesilada E, Sezik A. Survey on the traditional medicine in Turkey: semi-quantitative evaluation of the results, In: Singh VK, Govil JN, Hashmi S, Singh G. (Eds.). Recent Progress in Medicinal Plants. Vol. VII. Ethnomedicine and Pharmacognosy-II. Studium Press, LLC, Houston, Texas, 2003, pp. 389-412.

[8] Küpeli E, Kartal M, Aslan S, Yesilada E. Comparative evaluation of the anti-inflammatory and antinociceptive activity of Turkish Eryngium species. J Ethnopharmacol. 2006; 107: 32-37. [CrossRef]

[9] Marčetić MD, Petrović SD, Milenković MT, Niketić MS. Composition, antimicrobial and antioxidant activity of the extracts of Eryngium palmatum Pančić and Vis. (Apiaceae). Cent Eur J Biol. 2014; 9: 149-155. [CrossRef]

[10] Bouzergoune F, Ciavatta ML, Bitam F, Carbone M, Aberkane MC, Gavagnin, M. Phytochemical study of Eryngium triquetrum: isolation of polyacetylenes and lignans. Planta Med. 2016; 82: 1438-1445. [CrossRef]

[11] Ural IO, Kayalar H, Durmuskahya C, Cavus I, Ozbilgin A. In vivo antimalarial activity of methanol and water extracts of Eryngium thorifolium Boiss (Apiaceae Family) against P. berghei in infected mice. Trop J Pharm Res. 2014; 13: 13131317. [CrossRef] 
[12] Benmerache A, Magid AA, Berrehal D, Kabouche A, Voutquenne-Nazabadioko L, Messaili S, Abedini A, Harakat D, Kabouche Z. Chemical composition, antibacterial, antioxidant and tyrosinase inhibitory activities of glycosides from aerial parts of Eryngium tricuspidatum L. Phytochem Lett. 2016; 18: 23-28. [CrossRef]

[13] Çelik A, Aydınlık N, Arslan I. Phytochemical constituents and inhibitory activity towards methicillin-resistant Staphylococcus aureus strains of Eryngium species (Apiaceae). Chem Biodivers. 2011; 8: 454-459. [CrossRef]

[14] Usluer Ö, Duru ME, Harmandar M, Varol Ö. Muğla'ya Endemik İki Eryngium Türünün Kimyasal Bileşimleri. XIX. Ulusal Kimya Kongresi, Kuşadası, 2005; OKP157.

[15] Sefidkon F, Dabiri M, Alamshahi A. Chemical composition of the essential oil of Eryngium billardieri F. Delaroche from Iran. J Essent Oil Res. 2004; 16: 42-43. [CrossRef]

[16] Klein-Junior LC, Passos CS, Tasso de Souza TJ, Gobbi de Bitencourt F, Salton J, Bordignon SAL, Henriques AT. The monoamine oxidase inhibitory activity of essential oils obtained from Eryngium species and their chemical composition. Pharm Biol. 2016; 54: 1071-1076. [CrossRef]

[17] Sumitha KV, Prajitha V, Sandhya VN, Anjana S, Thoppil JE. Potential larvicidal principles in Eryngium foetidum L. (Apiaceae), an omnipresent weed, effective against Aedes albopictus skuse. J Essent Oil Bear Pl. 2014; 17: 1279-1286. [CrossRef]

[18] Merghache D, Boucherit-Otmani Z, Merghache S, Chikhi I, Selles C, Boucherit K. Chemical composition, antibacterial, antifungal and antioxidant activities of Algerian Eryngium tricuspidatum L. essential oil. Nat Prod Res. 2014; 28: 795-807. [CrossRef]

[19] Maggio A, Bruno M, Formisano C, Rigano D, Senatore F. Chemical composition of the essential oils of three species of Apiaceae growing wild in Sicily: Bonannia graeca, Eryngium maritimum and Opopanax chironium. Nat Prod Commun. 2013; 8: 841-844.

[20] Capetanos C, Saroglou V, Marin PD, Simic A, Skaltsa HD. Essential oil analysis of two endemic Eryngium species from Serbia. J Serb Chem Soc. 2007; 72: 961-965. [CrossRef]

[21] Ayoub N, Al-Azizi M, Konig W, Kubeczka K-H. Essential oils and a novel polyacetylene from Eryngium yuccifolium Michaux. (Apiaceae). Flavour Fragr J. 2006; 21: 864-868. [CrossRef]

[22] Thomas PS, Essien EE, Ntuk SJ, Choudhary MI. Eryngium foetidum L. essential oils: chemical composition and antioxidant capacity. Medicines. 2017; 4: 24-31. [CrossRef]

[23] Landoulsi A, Roumy V, Duhal N, Skhiri FH, Riviere C, Sahpaz S, Neut C, Benhamida J, Hennebelle T. Chemical composition and antimicrobial activity of the essential oil from aerial parts and roots of Eryngium barrelieri Boiss. and Eryngium glomeratum Lam. from Tunisia. Chem Biodivers. 2016; 13: 1720-1729. [CrossRef]

[24] Dehghanzadeh N, Ketabchi S, Alizadeh A. Essential oil composition and antibacterial activity of Eryngium caeruleum grown wild in Iran. J Essent Oil Bear Pl. 2014; 17: 486-492. [CrossRef]

[25] Cavaleiro C, Goncalves MJ, Serra D, Santoro G, Tomi F, Bighelli A, Salgueiro L, Casanova J. Composition of a volatile extract of Eryngium duriaei subsp. juresianum (M. Lainz) M. Lainz, signalised by the antifungal activity. J Pharm Biomed Anal. 2011; 54: 619-622. [CrossRef]

[26] Pala-Paul J, Copeland LM, Brophy JJ, Goldsack RJ. Essential oil composition of Eryngium paludosum (Moore et Betche) P.W. Michael: an endemic species from eastern Australia. J Essent Oil Res. 2008; 20: 416-419. [CrossRef]

[27] Pala-Paul J, Copeland LM, Brophy JJ, Goldsack RJ. Essential oil composition of Eryngium rosulatum P.W. Michael ined.: A new undescribed species from eastern Australia. Biochem Syst Ecol. 2006; 34: 796-801. [CrossRef]

[28] Abd-Elmonem AR, Shehab NG. Study of the volatile oil of Eryngium campestre 1. growing in Egypt. Bull Fac Pharm Cairo Univ. 2008; 44: 3379-3388.

[29] Morteza-Semnani K. Essential oil composition of Eryngium bungei Boiss. J Essent Oil Res. 2005; 17: 485-486. [CrossRef]

[30] Afoulous S, Ferhout H, Raoelison EG, Valentin A, Moukarzel B, Couderc F, Bouajila J. Chemical composition and anticancer, antiinflammatory, antioxidant and antimalarial activities of leaves essential oil of Cedrelopsis grevei. Food Chem Toxicol. 2013; 56: 352-362. [CrossRef]

[31] Lajnef HB, Ferioli F, Pasini F, Politowicz J, Khaldi A, D’Antuono LF, Caboni MF, Nasri N. Chemical composition and antioxidant activity of the volatile fraction extracted fromair-dried fruits of Tunisian Eryngium maritimum L. ecotypes. J Sci Food Agr. 2018; 98: 635-643. [CrossRef]

[32] Adams RP. Identification of essential oil components by Gas Chromatography/Mass Spectrometry, Allured Publ. Corp, Carol Stream, IL, 2007. 
[33] Tel G, Apaydın M, Duru ME, Öztürk M. Antioxidant and cholinesterase inhibition activities of three Tricholoma species with total phenolic and flavonoid contents: The edible mushrooms from Anatolia. Food Anal Method. 2012; 5: 495-504. [CrossRef]

[34] Blois MS. Antioxidant determinations by the use of a stable free radical. Nature. 1958; 181: 1199-1200. [CrossRef]

[35] Re R, Pellegrini N, Proteggente A, Pannala A, Yang M, Rice-Evans C. Antioxidant activity applying an improved ABTS radical cation decolorization assay. Free Radic Biol Med. 1999; 26: 1231-1237. [CrossRef]

[36] Apak R, Guclu K, Ozyurek M, Karademir SE, Ercag E. The cupric ion reducing antioxidant capacity and polyphenolic content of some herbal teas. . Int J Food Sci Nutr. 2006; 57: 292-304. [CrossRef]

This is an open access article which is publicly available on our journal's website under Institutional Repository at http://dspace.marmara.edu.tr. 